\title{
Alkaline phosphatase activities among planktonic communities in the northern Red Sea
}

\author{
Hong $\mathrm{Li}^{1}{ }^{1}$, Marcel J. W. Veldhuis ${ }^{2}$, Anton F. Post ${ }^{1, *}$ \\ ${ }^{1} \mathrm{H}$. Steinitz Marine Biology Laboratory, The Interuniversity Institute for Marine Science, PO Box 469, 88193 Eilat, Israel \\ ${ }^{2}$ Nederlands Instituut voor Onderzoek der Zee (NIOZ), PO Box 59, 1790 AB Den Burg, Texel, The Netherlands
}

\begin{abstract}
During a June 1996 cruise in the northern Red Sea, we studied spatial distributions of alkaline phosphatase (AP) activities in different plankton size fractions and in the aqueous fraction which passes through $0.2 \mu \mathrm{m}$ filters. AP proved to be a highly stable compound in the Red Sea and has potential use as an indicator for inorganic P-availability to planktonic communities. Depth profiles showed that aqueous and particulate alkaline phosphatase activities were highest in surface waters. The contribution of the aqueous fraction to total alkaline phosphatase activity varied between 42 and $74 \%$. The bulk of particulate alkaline phosphatase activity was associated with picoplankton (50 to $71 \%$ ) at all sampling sites. A good correlation was found between depth distributions of alkaline phosphatase activities and Synechococcus, suggesting that this abundant picoplanktonic cyanobacterium is a significant contributor to the enzyme activity in the northern half of the Gulf of Aqaba. Chlorophyll aspecific alkaline phosphatase activities were highest for plankton communities in the surface layers of the northern half of the Gulf. Alkaline phosphatase activities increased in the Gulf of Aqaba in water bodies traveling north, further away from the Straits of Tiran. At this narrow and shallow entrance to the Gulf, local turbulent conditions and coral reef flats inject phosphate into the productive layer. Plankton communities immediately north of the Straits showed basal levels of alkaline phosphatase activity, and phosphate supply presumably satisfied their P-demands. Based on the regulation of alkaline phosphatase synthesis, its secretion and stability, we proposed the use of alkaline phosphatase activities for a (partial) assessment of the P-status of marine planktonic communities. Such an assessment indicated that inorganic phosphate availability in the waters of the northern Gulf of Aqaba was persistently low during the period prior to sampling.
\end{abstract}

KEY WORDS: Marine picoplankton - Phosphate . $\mathrm{P}_{\mathrm{i}}$-limitation - Alkaline phosphatase activity . Synechococcus

\section{INTRODUCTION}

Assessment of which nutrient limits the primary production of marine phytoplankton is the subject of continuing research effort and debate. Although nitrogen is commonly considered as the growth limiting nutrient, no rigorous demonstration of nitrogen limitation has been presented (Hecky \& Kilham 1988). Evidence is largely based on the high demand of phytoplankton productivity for combined nitrogen; ambient concentrations of nitrate, nitrite and ammonium that are, more often than not, below detection limits; low Redfield ratios for N:P and geo-evolutionary considerations

·Addressee for correspondence.E-mail: anton@vms.huji.ac.il
(Harrison 1990, Garside \& Garside 1993, Falkowski 1997). Other evidence, however, challenges this notion as it has been shown that iron and phosphorus rather than nitrogen may become the limiting nutrient for marine productivity in certain bodies of water. Iron has been reported as the factor limiting phytoplankton productivity in large sections of the equatorial Pacific and the Southern Ocean (Martin et al. 1994, Coale et al. 1996). P-limitation of phytoplankton production was reported for the eastern basin of the Mediterranean Sea (Krom et al. 1991, Krom et al. 1993). Cell cycle studies of the abundant phytoplanktonic cyanobacterium Synechococcus in Mediterranean waters following phosphate additions suggest that P-limitation might be encountered more frequently than previously 
thought (Vaulot et al. 1996), Moreover, the N:P ratio in the Sargasso Sea is often in excess of the Redfield ratio (16:1), and bacterial communities from this sea were demonstrated to be P-limited (Cotner et al. 1997).

Orthophosphate is the main, and possibly sole, Psource taken up directly by algal and bacterial planktonic communities. However, orthophosphate concentrations in many bodies of water are too low to support their growth and biomass production. A variable fraction of dissolved phosphate in the marine environment is bound to organic compounds, and phosphate supply depends to a large extent on its regeneration from dissolved organic matter (Harrison 1980, 1992). Alkaline phosphatase (AP) and 5'-nucleotidase activities contribute significantly to phosphate regeneration in aquatic ecosystems (see e.g. Ammerman \& Azam 1985, 1991a, b, Chróst 1991, James et al. 1991). Both enzymes are localized to the cell surface, but they differ in substrate specificity. 5'-Nucleotidase is capable of hydrolyzing nucleotides only and its activities appear to be a function of bacterial density rather than P-availability (Ammerman \& Azam 1991a, b). AP is capable of hydrolyzing a wide range of organic $\mathrm{P}$-compounds. AP therefore has potential importance in inorganic phosphate-deplete, oligotrophic waters where growth of plankton depends on P-regeneration (Cotner et al. 1997). Extracellular AP activity is inducible, that is, the biosynthesis of the enzyme is switched on when inorganic phosphate supply is low and the enzyme is subsequently localized to the cell exterior. This activity has been used as an indicator of the P-status of phytoplankton communities in freshwater ecosystems (Healey 1978, Cotner \& Wetzel 1991). In the common cyanobacterium Synechococcus both P-limitation and. supply of organic P-sources induce AP activities in parallel with an enhanced phosphate uptake capacity (Ray et al. 1991, Aiba et al. 1993, Scanlan et al. 1993, Donald et al. 1997). Marine phytoplankton species like Synechococcus and Prochlorococcus are abundantly present in environments where the inorganic P-supply is low (Parpais et al. 1996, Vaulot et al. 1996) and they would thus benefit from this adaptive potential in the competition for available phosphorus.

The Gulf of Aqaba is a warm, stratified body of water and its photic layer is depleted of inorganic nutrients during most of the year, comparable to other oligotrophic seas. Primary production in the Gulf of Aqaba and the northern Red Sea ranges from 20 to $110 \mathrm{mg} \mathrm{C}$ $\mathrm{m}^{-2} \mathrm{~d}^{-1}$ and chlorophyll a concentrations vary between 0.02 and $0.8 \mathrm{mg} \mathrm{m}^{-3}$ (Levanon-Spanier et al. 1979). Both combined inorganic nitrogen and phosphate drop below detection limits during the summer stratification period (Klinker et al. 1978, Lindell \& Post 1995). Although little is known about nutrient control of primary productivity in the Gulf of Aqaba, phosphate should be considered a potentially limiting nutrient (Reiss \& Hottinger 1984). In order to assess the inorganic P-status for planktonic communities in the northern Red Sea, where both dissolved inorganic nitrogen and phosphorus compounds are below detection levels, we used AP activity as an assay. Although AP activities have been studied in marine algae (Yentsch et al. 1972, Vargo \& Shanley 1985, Tomas \& Baden 1993) and in mesocosms (Carlsson \& Graneli 1993, Sobecky et al. 1996), its potential as an indicator for Plimitation in nutrient poor, subtropical seas has not been reported.

\section{MATERIALS AND METHODS}

Study area. The Gulf of Aqaba, a side-arm of the northern Red Sea, is a narrow, deep basin which is $180 \mathrm{~km}$ long, on average $14 \mathrm{~km}$ wide and has a maximum depth of $1800 \mathrm{~m}$. It is connected to the Red Sea by the Straits of Tiran, a shallow sill with a maximum depth of $242 \mathrm{~m}$. Being surrounded by desert, the Gulf has high evaporation rates averaging $1 \mathrm{~cm} \mathrm{~d} \mathrm{~d}^{-1}$. Nutrient levels, chlorophyll a concentrations and primary productivity all testify to its oligotrophic nature during the stratification period (Reiss \& Hottinger 1984). The input of freshwater and inorganic nutrients from land based sources is negligible. The Straits of Tiran and the prevailing climatic conditions cause a thermohaline circulation in the Gulf of Aqaba with an influx of warm, nutrient-depleted surface waters from the Red Sea counterbalanced by an efflux of deep more dense waters (Klinker et al. 1976, Reiss \& Hottinger 1984, Wolf-Vecht et al. 1992).

Sampling. During a research cruise on board the RV 'University I' between 2 and 10 June 1996, water samples were taken from the Gulf of Aqaba and the northern Red Sea. Hydrocast samples were taken at 3 sampling stations ( $A, B$ and $M$ ) located in the northern half of the Gulf of Aqaba (Fig. 1). Water was sampled with 5 l Niskin bottles equipped with reversing pressure gauges (SiS GmbH model RPM 2000) at depths of 1 , $20,40,60,80,100,125,150$ and $200 \mathrm{~m}$. In addition we collected surface samples from a further 9 sites spaced at roughly equal distances on a transect, from its entrance at the Straits of Tiran to the northern tip of the Gulf (Fig. 1)

Size fractionation. Water samples were passed immediately through a $100 \mu \mathrm{m}$ mesh to exclude large zooplankton and phytoplankton. The samples were subsequently fractionated into different size groups. Total plankton $(0.2$ to $100 \mu \mathrm{m})$ was obtained by filtering $100 \mathrm{ml}$ water samples onto $0.2 \mu \mathrm{m}$ polycarbonate filters (Poretics) by filtration at $<125 \mathrm{~mm} \mathrm{Hg}$. Nanoplankton (2 to $20 \mu \mathrm{m}$ ) was collected on $2 \mu \mathrm{m}$ polycar- 
bonate filters (Poretics) after passing the sample through a $20 \mu \mathrm{m}$ mesh. Picoplankton (0.2 to $2 \mu \mathrm{m})$ was collected on $0.2 \mu \mathrm{m}$ polycarbonate filters after passing the sample through a $2.0 \mu \mathrm{m}$ polycarbonate filter (Poretics) by vacuum filtration at $<125 \mathrm{~mm} \mathrm{Hg}$. Microplankton (20 to $100 \mu \mathrm{m}$ ) was estimated by subtraction of the combined nanoplankton and picoplankton fraction $(0.2$ to $20 \mu \mathrm{m})$ from total plankton. The aqueous phase was sampled by collecting the filtrate of samples passed through a $0.2 \mu \mathrm{m}$ polycarbonate filter. All samples were stored in the dark at $4^{\circ} \mathrm{C}$ in $20 \mathrm{ml}$ vials prior to analysis.

Determinations. For the determination of soluble reactive phosphorus, $250 \mathrm{ml}$ seawater were precipitated with $6.25 \mathrm{ml} 1 \mathrm{M} \mathrm{NaOH}$ (Karl \& Tien 1992) and stored at $4^{\circ} \mathrm{C}$. Samples were then centrifuged for $15 \mathrm{~min}$ at 3000 rpm $(1470 \times g)$ and the pellet was redissolved in $0.2 \mathrm{M} \mathrm{HCl}$. Phosphate was then determined spectrophotometrically at $800 \mathrm{~nm}$ in $10 \mathrm{~cm}$ cuvettes according to Murphy \& Riley (1962). The detection limit of this method is about $10 \mathrm{nM}$.

Chlorophyll a was determined from $250 \mathrm{ml}$ water samples filtered on $25 \mathrm{~mm}$ GF/F filters and subsequently extracted in $10 \mathrm{ml} 90 \%$ acetone for $24 \mathrm{~h}$ at $4^{\circ} \mathrm{C}$. Chlorophyll a concentrations were calculated from values of fluorescence emission of extracts before and after acidification with $\mathrm{HCl}$ as measured on a Turner Designs 10-000R fluorometer (Venrick et al. 1987). Two $2 \mathrm{ml}$ water samples were preserved with paraformaldehyde at $\mathrm{pH} 7.0$ at a final concentration of $0.4 \% \mathrm{v} / \mathrm{v}$ and directly frozen and stored in liquid nitrogen. Phytoplankton counts were performed with an Epics XI (Coulter Inc.) flow cytometer. Phytoplankton groups were distinguished on the basis of forward scatter relative to $0.474 \mathrm{\mu m}$ beads (cell size) and pigment fluorescence. Yellow (phycoerythrin) and red (chlorophyll a) fluorescence were determined from excitation at $488 \mathrm{~nm}$.

In comparison to high biomass bodies of water and laboratory cultures, AP activities per unit volume in oligotrophic seawater are low. For this reason 100 to $200 \mathrm{ml}$ of (size fractionated) seawater samples were concentrated on $0.2 \mu \mathrm{m}$ polycarbonate filters (Poretics) and immersed in $2 \mathrm{ml}$ of filtered seawater. AP activity was determined after addition of $100 \mu \mathrm{l}$ of $10 \mathrm{mM} \mathrm{p}$ nitrophenylphosphate (PNP) as a substrate, $270 \mu \mathrm{l}$ trisglycine buffer $(50 \mathrm{mM}, \mathrm{pH} 8.5)$ and 27 pl of $1 \mathrm{mM}$ $\mathrm{MgCl}_{2}$. Following incubation for $24 \mathrm{~h}$ at $37^{\circ} \mathrm{C}$ on an

orbital shaker at $100 \mathrm{rpm}$, the concentration of $\mathrm{p}$-nitrophenol formed in the reaction was determined spectrophotometrically from the absorbance at $400 \mathrm{~nm}$, using a molar extinction coefficient of $18000 \mathrm{~cm}^{-1}$ (Wynne 1981). Appropriate incubation times were determined by testing triplicate filtered seawater samples over a $48 \mathrm{~h}$ incubation period. AP activities were detectable after $10 \mathrm{~h}$ and increased in a linear fashion over $24 \mathrm{~h}$ incubation periods and longer (data not shown). In order to assess the stability of AP activity in seawater, $0.2 \mathrm{\mu m}$ filtered seawater samples were incubated in both darkness at $4^{\circ} \mathrm{C}$ and light at $40 \mu \mathrm{mol}$ photons $\mathrm{m}^{-2} \mathrm{~s}^{-1}$ and $24^{\circ} \mathrm{C}$, simulating sample storage and natural conditions respectively. Triplicate samples over a $50 \mathrm{~d}$ time series were transferred to $-75^{\circ} \mathrm{C}$ until assayed as described above. Statistical analyses were performed using the 'Statistica for Windows' software package (Statsoft, Inc.)

\section{RESULTS}

\section{Stability of alkaline phosphatase in seawater}

AP is an enzyme which is released to the environment through either cell lysis or excretion. Depending on its own lifetime and the prevailing environmental conditions, the enzyme may remain active outside the cell, and should then be detectable in the aqueous phase as freely dissolved activity. Boiled seawater and distilled water incubations, run as control experiments, 


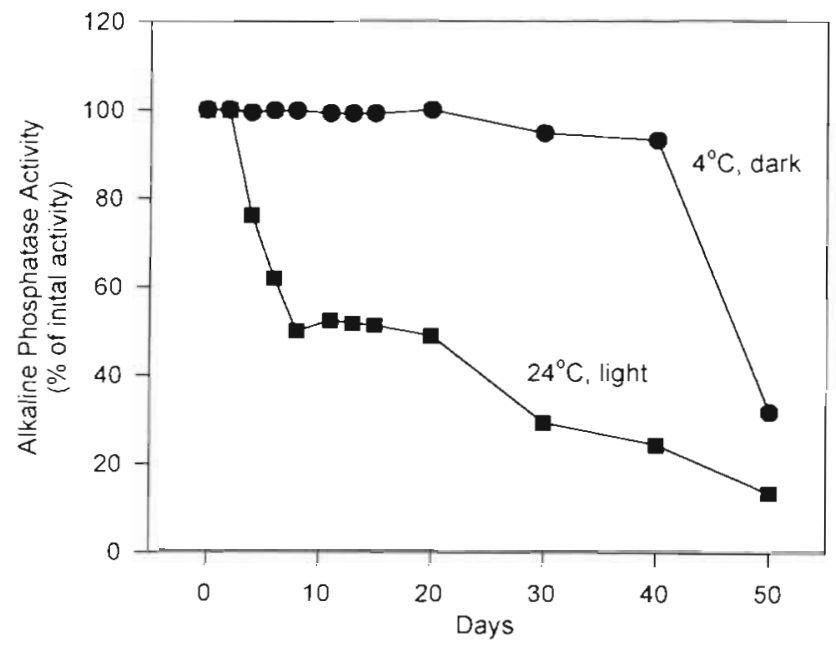

Fig. 2. Time-dependent change in alkaline phosphatase activity (expressed as percentage of initial activity) in particle-free seawater incubated in clarkness at $4^{\circ} \mathrm{C}(-)$ and in the light $\left(40 \mu \mathrm{mol}\right.$ photons $\left.\mathrm{m}^{-2} \mathrm{~s}^{-1}\right)$ at $24^{\circ} \mathrm{C}(\boldsymbol{\square})$. Data are average values of triplicate samples

did not show any PNP degradation. Filtered $(0.2 \mu \mathrm{m})$, particle-free seawater samples from the head of the Gulf, kept in the dark at $4^{\circ} \mathrm{C}$, retained AP activities at the level of initial activity (10 nmol PNP $\mathrm{ml}^{-1} \mathrm{~h}^{-1}$ ) over a $40 \mathrm{~d}$ period (Fig. 2). AP activities declined drastically after Day 40 and on Day 50 AP activity was reduced to $25 \%$. When identical water samples were kept at an irradiance of $40 \mu \mathrm{mol}$ photons $\mathrm{m}^{-2} \mathrm{~s}^{-1}$ at $24^{\circ} \mathrm{C}$, AP activities remained stable for $2 \mathrm{~d}$, after which they steadily decreased to about $50 \%$ of the initial activity in $8 \mathrm{~d}$ and to 25 to $30 \%$ activity only after 30 to $40 \mathrm{~d}$ (Fig. 2). Light and temperature conditions used can be considered representative of those encountered in the northern Red Sea. In the presence of suitable organic P-sources, aqueous AP may thus contribute significantly to P-regeneration in these waters. AP activities thus potentially reflect the

Fig. 3. $(a, b, c)$ Depth distributions of seawater. temperature (solid line) and chlorophyll a concentration ( $\mathbf{V}$ ) at sampling Stns A, B and M respectively. ( $d, e, f)$ Aqueous alkaline phosphatase activity (-) and alkaline phosphatase activities associated with particulate matter $(0.2$ to $100 \mu \mathrm{m})(0)$ at Stns A, B and M. $(g, h, i)$ Depth distributions of Synechococcus ( and picoeukaryotic algae ( $)$ at Stns $A, B$ and $M$ inorganic phosphate $\left(\mathrm{P}_{1}\right)$ history of the plankton community over a period of up to $1.5 \mathrm{mo}$. This consideration formed the basis for our subsequent study of the spatial patterns in AP activities in the Gulf of Aqaba.

\section{Depth profiles of alkaline phosphatase activity}

The waters in the northern half of the Gulf of Aqaba exhibited a complex thermal structure with multilayer stratification in June 1996 (Fig. 3). $P_{1}$ concentrations were near the detection limit in the upper $200 \mathrm{~m}$ of the water column. Average concentrations along the depth profiles were $9.6 \pm 2.2,14.1 \pm 10.7$ and $9.8 \pm 5.1 \mathrm{nmol} \mathrm{l}^{-1}$ at Stns $A, B$ and $M$ respectively. Chlorophyll a showed typical depth distributions, with concentrations ranging between 0.05 and $0.25 \mu \mathrm{g} \mathrm{l}^{-1}$ and the presence of a deep chlorophyll maximum apparent at all sites temperature $\left({ }^{\circ} \mathrm{C}\right)$
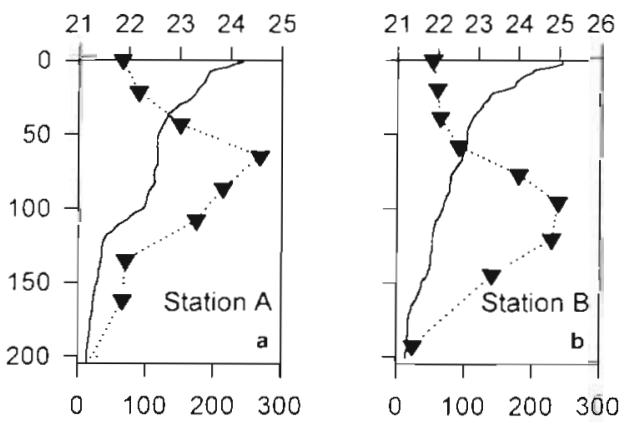

202122232425



Chlorophyll a (ng ! ! $)$
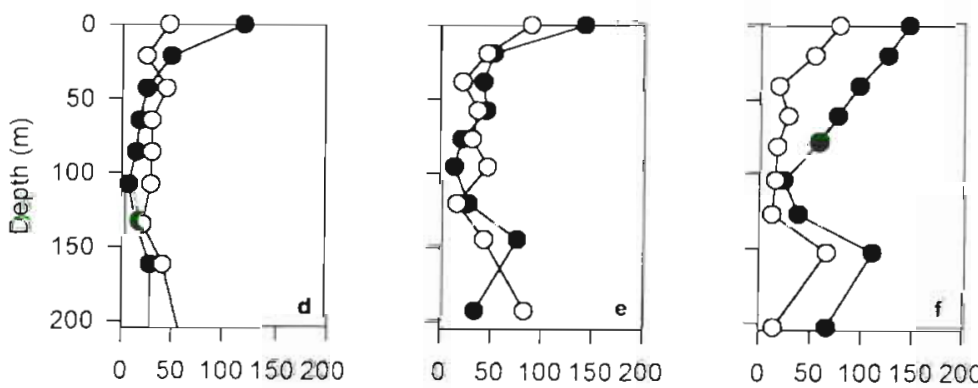

Alkaline Phosphatase Activity
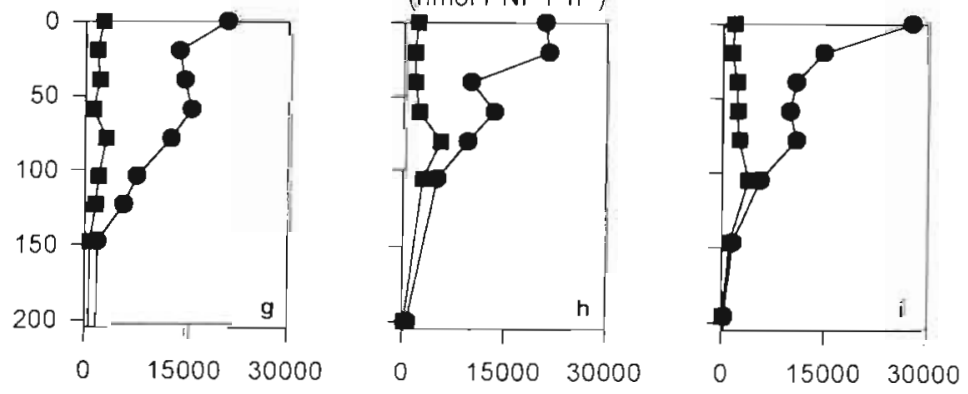

Cells $\mathrm{ml}^{-1}$ 
(Fig. 3). Depth profiles of AP activities associated with the total particulate $(0.2$ to $100 \mu \mathrm{m})$ and aqueous $(<0.2 \mu \mathrm{m})$ fractions showed very similar patterns at all sampling stations (Fig. 3). AP activities of both the aqueous and particulate fractions were highest in the surface layers with typical values of 150 and 40 to $80 \mathrm{nmol} \mathrm{PNP} \mathrm{l} \mathrm{P}^{-1} \mathrm{~h}^{-1}$ respectively. AP activities quickly decreased with depth for both fractions and they reached a minimum at depths of 100 to $125 \mathrm{~m}$, the bottom of the photic zone. Depth distributions showed that the layers with highest AP activities were located near the surface, well above the deep chlorophyll maximum (Fig. 3). Depth distributions of picophytoplankton showed that Synechococcus was abundantly present in near the surface layers with concentrations reaching $2.5 \times 10^{4}$ cells $\mathrm{ml}^{-1}$

(Fig. 3). Eukaryotic algae were present at 2 to $3 \times 10^{3}$ cells $\mathrm{ml}^{-1}$ with a slight maximum at the depths of the chlorophyll maximum. The smallest picophytoplankton representative, Prochlorococcus, was present in insignificant numbers $\left(<10^{3}\right.$ cells $\left.\mathrm{ml}^{-1}\right)$ and thus its contribution to phytoplankton biomass was negligible. Depth profiles determined during a second visit to the sampling sites in the same week confirmed the previous observed patterns for all parameters with the distinction of slightly lower AP activities in surface layer samples: mean AP activities for all stations were $113 \pm$ $46 \mathrm{nmol}$ PNP $\mathrm{l}^{-1} \mathrm{~h}^{-1}$ (aqueous fraction) and $55 \pm 24$ nmol PNP $\mathrm{l}^{-1} \mathrm{~h}^{-1}$ (particulate fraction). A closer inspection of the depth profile data showed a trend whereby the percentage contribution of aqueous AP activity at all depths increased with distance from the head of the Gulf. Aqueous AP activity contributed $42 \pm 17 \%$ and $51 \pm 13 \%$ of the combined aqueous and particulate activities at Stns $\mathrm{A}$ and $\mathrm{B}$ in the northern section of the Gulf to $74 \pm 13 \%$ at $\mathrm{Stn} M$ in the central section.

\section{Alkaline phosphatase activity along a surface water transect}

During stratification, $\mathrm{P}_{\mathrm{i}}$-input into the photic layer of the Gulf of Aqaba occurs only with the entry of Red Sea waters through the Straits of Tiran. $P_{i}$ is injected into the surface waters of the Gulf with the passage of water over extensive coral reef flats (Korpal 1991) and from deeper layers by local turbulence at the Straits (Murray et al. 1984). One thus expects a gradient of decreasing $\mathrm{P}_{1}$-availability when travelling from the Straits to the more northern parts of the Gulf, with this being reflected in increasing AP activities. Since AP activity was most pronounced in the surface layers of the water column, we decided to determine surface AP activities along a transect from the northern Red Sea to Stn A in the northern tip of the Gulf of Aqaba. The AP activities in the aqueous fraction were significantly higher than those of the particulate fraction at all sampling sites (Fig. 4) and accounted for $79 \pm 10 \%$ of the combined activities. In the northern half of the Gulf of Aqaba both particulate and aqueous AP activities were obviously higher than those in the southern half. Whereas aqueous and particulate AP activities along the transect showed parallel spatial patterns, these differed from the pattern of surface chlorophyll a concentrations, which were higher in the southern half of the Gulf (Fig. 4). At Stn 4, just north of the Straits, we observed a 4 -fold increase in chlorophyll a. AP activities of the particulate and aqueous fractions were strongly correlated (Pearson correlation coefficient, $r_{p}=0.52$; $\mathrm{p}<0.001 ; \mathrm{n}=54$ ) for both samples taken along depth profiles in the northern section of the Gulf and along the surface transect (Fig. 5). This finding suggest a relationship between the 2 activities and both may be indicators of the P-status of the plankton community.

\section{Alkaline phosphatase activities in different plankton size fractions}

The typical spatial distribution of AP activities described above raises questions about the source of the aqueous AP activity. In order to assess the contribution of different plankton size fractions to overall activity we size-fractionated plankton samples into pico-, nano-, and microplankton fractions and determined AP activities of each separately. Picoplankton 


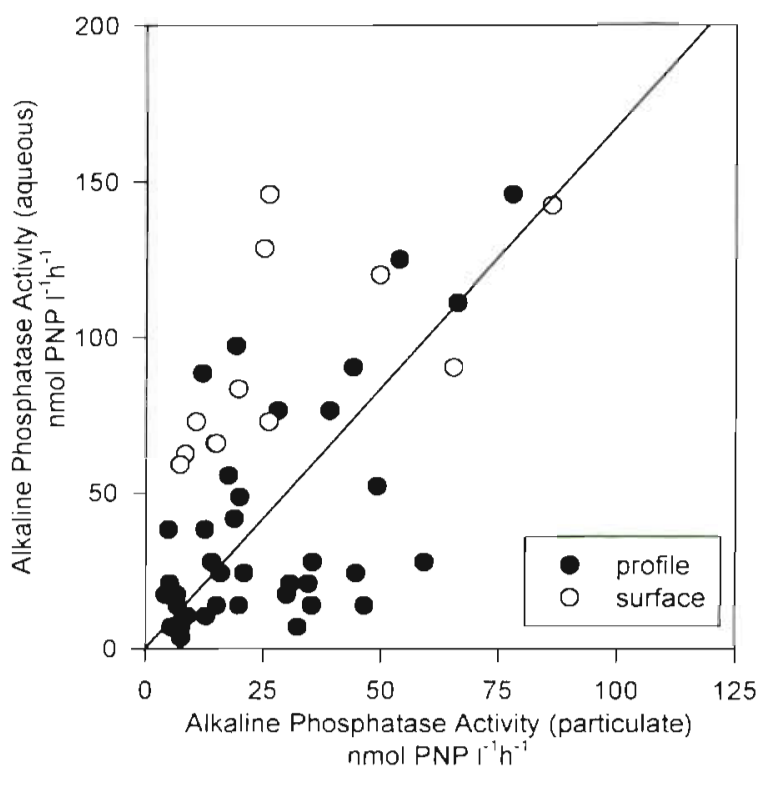

Fig. 5. Aqueous akaline phosphatase activity as a function of particulate alkaline phosphatase activity for depth profiles $(\bullet$ at Stns $A, B$ and $M$ in the Gulf of Aqaba and surface samples (O) of the northern Red Sea and the Gulf of Aqaba along a south-north transect

contributed $63 \%$ of total particulate activity for all samples taken at Stns A, B and M. Nanoplankton contributed $20 \%$ and microplankton $17 \%$. While the picoplankton contribution was always most pronounced, the relative contribution of pico-, nano-, and microplankton fractions to total particulate AP activities varied with location in the Gulf of Aqaba (Table 1). Interestingly, the picoplankton contribution rose from 50 to $71 \%$ moving south, with a decline in contribution from 37 to $3 \%$ by microplankton. Size-fractionated activities for surface samples taken along the southnorth transect were similar to the mean of those observed along depth profiles (Table 1). Stepwise mul-

Table 1. Relative contribution (mean $\pm \mathrm{SE}$ ) of different plankton size fractions to alkalıne phosphatase activities associated with total particulate matter along depth gradients at Stns $A$. $B$ and $M$ and in surface waters along a transect from the northern Red Sea (Stn 1) to the northern tip of the Gulf of Aqaba (Stn A)

\begin{tabular}{|c|c|c|c|}
\hline \multirow[t]{2}{*}{ Sampling site } & \multicolumn{3}{|c|}{$\begin{array}{c}\text { Alkaline phosphatase activity } \\
\text { ( } \% \text { of total) }\end{array}$} \\
\hline & $\begin{array}{c}\text { Pico- } \\
\text { plankton } \\
(0.2-2.0 \mu \mathrm{m})\end{array}$ & $\begin{array}{c}\text { Nano- } \\
\text { plankton } \\
(2.0-20 \mu \mathrm{m})\end{array}$ & $\begin{array}{l}\text { Micro- } \\
\text { plankton } \\
\text { (>20 } \mathrm{\mu m})\end{array}$ \\
\hline Stn A (depth profile) & $50 \pm 13$ & $12 \pm 4$ & $37 \pm 15$ \\
\hline Stn B (depth profile) & $66 \pm 18$ & $20 \pm 8$ & $14 \pm 15$ \\
\hline Stn $M$ (depth profile) & $71 \pm 5$ & $27 \pm 8$ & $3 \pm 4$ \\
\hline Surface transect & $62 \pm 18$ & $20 \pm 9$ & $18 \pm 18$ \\
\hline
\end{tabular}

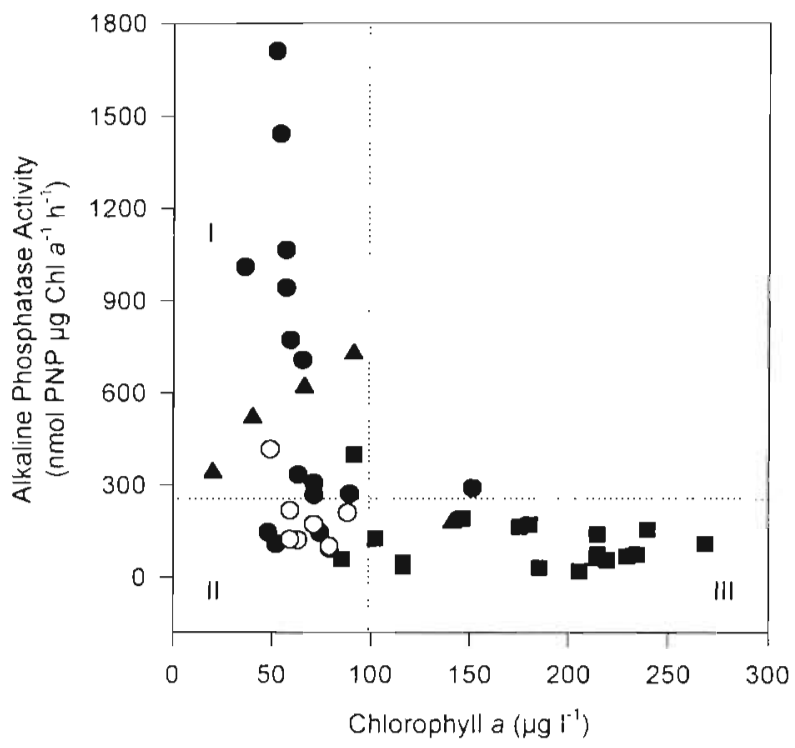

Fig. 6. Chlorophyll a-specific alkaline phosphatase activities as a function of chlorophyll a concentrations for samples taken from 0 to $60 \mathrm{~m}$ in the northern half $(\bullet)$ and southern half (O) of the Gulf, from 60 to $120 \mathrm{~m}(\boldsymbol{\nabla})$, and from $>120 \mathrm{~m}$ ( $\mathbf{\Delta}$ ). I, II and III denote arbitrary areas consistent with P-depleted, low $\mathrm{P}$ and $\mathrm{P}$-replete conditions respectively

tiple regression of aqueous AP activity versus distance from head of the Gulf, depth and the different size fractions revealed that approximately $44 \%$ of the variance in the aqueous AP activity was derived from the picoplankton fraction, $16 \%$ from differences in distance and only $3 \%$ from differences in depth (multiple $\mathrm{R}=0.72 ;$ adjusted $\mathrm{R}^{2}=0.45 ; \mathrm{n}=35 ; \mathrm{p}<0.002$ ). These findings suggest that most AP activity in the water column (particulate and aqueous) was derived from the picoplankton fraction. The depth distributions of the abundant picoplankter Synechococcus were similar to those of AP activities (Fig. 3) and its abundance showed a strong correlation with both aqueous $\left(\mathrm{r}_{p}=\right.$ $0.73 ; \mathrm{p}<0.001 ; \mathrm{n}=20)$ and particulate $\left(\mathrm{r}_{\mathrm{p}}=0.63 ; \mathrm{p}<\right.$ $0.005 ; \mathrm{n}=20$ ) AP activities. This indicates that $53 \%$ of variation in aqueous activity and $39 \%$ of that in particulate activity can be explained from variation in Synechococcus cell numbers.

Patterns of chlorophyll a concentrations along depth profiles and the surface transect were distinctly different from those for AP activities. A plot of all combined data of chlorophyll a specific AP activity versus chlorophyll a concentration shows an exponential decrease in activity with increasing chlorophyll a levels (Fig. 6). Inspection of 3 arbitrarily defined regions (I, II and III in Fig. 6) reveals that group III consists nearly exclusively of observations from the bottom half of the photic zone (60 to $150 \mathrm{~m}$ deep). Groups I and II were both made up of observations from the upper half of the photic layer ( 0 to $60 \mathrm{~m}$ ), with the distinction that 
most data points from the southern half of the Gulf of Aqaba (open circles) were located in group II and data in group I were mostly from the northern half (solid circles).

\section{DISCUSSION}

The major findings of our study are (1) planktonic communities showed AP activities in $\mathrm{P}_{\mathrm{i}}$-depleted waters, (2) AP activities in particle-free seawater showed a surprising longevity and (3) depth distributions of AP activity correlated with those of the abundant picoplankter Synechococcus AP activitities were detected in both aqueous and particulate fractions throughout the stratified photic layer of the Gulf of Aqaba, but were maximal in the surface layer. Aqueous activities were stable over extended periods ( 2 to $40 \mathrm{~d}$ ), after which enzyme activities reached a minimal level at both low and ambient temperatures. The relevance of long AP life-times has not been discussed for the marine environment so far. The strong correlation between particulate and aqueous AP activities implies that the AP produced by the planktonic community is subsequently released to the surrounding waters. During a period of stable stratification in June 1996, inorganic phosphate $\left(P_{1}\right)$ concentrations were $<15 \mathrm{nM}$ in the upper 150 to $200 \mathrm{~m}$, low enough to become limiting for phytoplankton productivity (Krom et al. 1991, Krom et al. 1993, Vaulot et al. 1996, Scanlan et al. 1997). In contrast to other plankton groups phytoplankton satisfy their P-demand from $\mathrm{P}_{1}$-supply (Harrison 1980). They may therefore be responsible for significant extracellular AP activity (Ammerman \& Azam 1991b, Cotner \& Wetzel 1991). Samples from the upper $60 \mathrm{~m}$ of the water column in the northern half of the Gulf were characterized by low chlorophyll a concentrations and high AP activities (see Figs. $3 \& 6$ ). These findings are consistent with the occurrence of $\mathrm{P}_{1}$-limiting conditions in the northern part of the Gulf which are reflected in an adaptive response of the planktonic community to low ambient $P_{j}$-levels. Samples from the southern half of the Gulf had experienced phosphate-replete conditions in their recent past at the Straits of Tiran. Here, phosphate is injected into Gulf of Aqaba surface waters from deeper layers by local turbulence at this location (Murray et al. 1984) and through P-losses from coral reef communities (Korpal 1991). Indeed we observed elevated chlorophyll a concentrations and low chlorophyll a-specific alkaline phosphatase activities in surface samples from the southerly half of the Gulf.

Although picoplankton have a high surface:volume ratio, advantageous for meeting their nutrient de- mands (Chisholm 1992), AP activities were mostly associated with this size fraction, suggesting that they respond most strongly to $\mathrm{P}_{1}$-depletion. Depth distributions of AP activities in the Gulf of Aqaba bore a high similarity to those of the picoplanktonic cyanobacterium Synechococcus, whose maximal concentrations are found in the upper $50 \mathrm{~m}$. Prochlorococcus (when present), eukaryotic algae and heterotrophic bacteria have distinctly different depth distributions (Lindell \& Post 1995, Post \& Angel unpubl. results). $P_{\mathrm{i}}$-depletion causes a prompt induction of AP activity by the freshwater Synechococcus strain PCC 7942, and a large part of this activity is found as free dissolved enzyme activity (Block \& Grossman 1988). Marine Synechococcus strain WH7803 responds to $\mathrm{P}_{\mathrm{i}}$-limitation with induced synthesis of a high affinity phosphate uptake system (Scanlan et al. 1993) and of organic P-uptake capacity (Donald et al. 1997). Recently, Synechococcus was shown to contribute significantly to ATP (a substrate for AP) and $P_{1}$-uptake in the $P_{i}$-deplete waters of the Sargasso Sea (Cotner et al. 1998). Synechococcus was shown to be more susceptible to $\mathrm{P}_{\mathrm{i}}$-limitation than Prochlorococcus (Parpais et al. 1996, Vaulot et al. 1996) and can thus be expected to induce AP synthesis at a less advanced stage of P-depletion.

Induction of extracellular AP activities is a common response of planktonic communities to low inorganic P-supply and it may convey information about their Phistory (see e.g. Chróst 1991, Wynne \& Bergstein-Ben Dan 1995, Cotner et al. 1997). $\mathrm{P}_{j}$-starvation immediately induces the synthesis of AP, following which maximal activity can be detected at the cell's exterior within 2 to 12 h (Vargo \& Shanley 1985, Block \& Grossman 1988). In the freshwater Synechococcus strain PCC 7942, AP may be released to the aqueous environment and these activities are detected between 4 to 12 h (Block \& Grossman 1988). Its long lifetime (2 to $40 \mathrm{~d}$, this study) exceeds the average generation time of most phytoplankton species (Lande et al. 1989, Vaulot \& Partensky 1992, DiTullio et al. 1993, Liu et al. 1995). On the basis of these considerations we can compare the relative levels of aqueous and particulate AP activities and consider the hypothetical model for $\mathrm{P}_{\mathrm{i}}$-availability and AP levels of planktonic communities found in Table 2 .

Table 2. Hypothetical model for $\mathrm{P}_{\mathrm{i}}$-availability and AP levels of planktonic communities

\begin{tabular}{|c|c|c|}
\hline Aqueous & Particulate & P-history \\
\hline Absent & Low or absent & No $P_{1}$-limitation \\
\hline Low & High & Recent $\mathrm{P}_{\mathrm{i}}$-limitation ( $\mathrm{h}$ to $\mathrm{d}$ ) \\
\hline High & High & Persisting $P_{\mathrm{p}}$-limitation ( $\mathrm{d}$ to $\mathrm{wk}$ ) \\
\hline High & Low or absent & Recent relief from $P_{i}$-limitation \\
\hline
\end{tabular}


On the basis of this division we consider the situation encountered in the northern half of the Gulf of Aqaba, where aqueous AP contributed 42 to $74 \%$ of combined particulate and aqueous activity, as one of persistent $\mathrm{P}_{\mathrm{i}}$-limitation. The fact that aqueous AP activities were proportional to those of the particulate matter at all depths suggests that both aqueous and particulate AP activities reflect the low $\mathrm{P}_{\mathrm{i}}$ - history of this body of water up to the day of sampling.

Acknowledgements. This work was carried out on natural samples taken during a research cruise with financial support from a 'Red Sea Program' grant no. 03F0151A by the German Ministry for Education, Science, Research and Technology. This study was further supported by the 'Moshe Shilo' Minerva Center for Marine Biogeochemistry, Minerva StiftungGesellschaft für die Forschung, München, Germany. Special thanks are due to Gitai Yahel for help in statistical analyses, and to Ulrich Sommer and Debbie Lindell for critical reading of the manuscript.

\section{LITERATURE CITED}

Aiba H, Nagaya $M$, Takeshi $M$ (1993) Sensor and regulator proteins from the cyanobacterium Synechococcus species PCC7942 that belong to the bacterial signal-tranduction protein families: implication in the adaptive response to phosphate limitation. Mol Microbiol 8:81-91

Ammerman JW, Azam F (1985) Bacterial 5'-nucleotidase in aquatic ecosystems: a novel mechanism of phosphorus regeneration. Science 227:1338-1340

Ammerman JW, Azam F (1991a) Bacterial 5'-nucleotidase activity in estuarine and coastal marine waters: characterization of enzyme activity. Limnol Oceanogr 36:1427-1436

Ammerman JW, Azam F (1991b) Bacterial 5'-nucleotidase activity in estuarine and coastal marine waters: role in phosphorus regeneration. Limnol Oceanogr 36:1437-1447

Block MA, Grossman AR (1988) Identification and purification of a derepressible alkaline phosphatse from Anacystis nidulans R2. Plant Physiol 86:1179-1184

Carlsson P, Graneli E (1993) Availability of humic bound nitrogen for coastal phytoplankton. Estuar Coast Shelf Scl 36: $433-447$

Chisholm SW (1992) Phytoplankton size. In: Falkowski PG Woodhead $A D$ (eds) Primary productivity and biogeochemical cycles in the sea, Vol 43. Plenum Press, New York, p 213-237

Chróst RJ (1991) Microbial enzymes in aquatic environments. Springer Verlag, Berlin

Coale KH, Johnson KS, Fitzwater SE, Gordon RM, Tanner S, Chavez FP, Ferioli L, Sakamoto C, Rogers P, Millero F, Steinberg P, Nightingale P, Cooper D, Cochlan WP, Landry MR, Constantinou J, Rollwagen $G$, Trasvina A, Kudela R (1996) A massive phytoplankton bloom induced by an ecosystem-scale iron fertilization experiment in the equatorial Pacific Ocean. Nature 383:495-501

Cotner JB, Ammerman JW, Peele ER, Bentzen E (1997) Phosphorus limited plankton growth in the Sargasso Sea. Aquat Microbial Ecol 13:141-149

Cotner JB, Ammerman JW, Van Dijken G, Lehman W (1998) Cell-specific dissolved inorganic and organic $\mathrm{P}$ incorporation in the Sargasso Sea. EOS Trans Am Geophys Union 79:168

Cotner JB, Wetzel RG (1991) Bacterial phosphatases from dif- ferent habits in a small, hardwater lake. In: Chróst RJ (ed) Microbial enzymes in aquatic environments. SpringerVerlag, New York, p 187-205

DiTullio GRM, Hutchins DA, Bruland KW (1993) Interaction of iron and major nutrients controls phytoplankton growth and species composition in the tropical North Pacific Ocean. Limnol Oceanogr 38:495-508

Donald KM, Scanlan DJ, Carr NG, Mann NH, Joint I (1997). Comparative phosphorus nutrition of the marine cyanobacterium Synechococcus WH7803 and the marine diatom Thalassiosira weisflogii. J Plankton Res 19:1793-1813

Falkowski PG (1997) Evolution of the nitrogen cycle and its influence on the biological sequestration of $\mathrm{CO}_{2}$ in the ocean. Nature 387:272-275

Garside C, Garside JC (1993) The 'f-ratio' on $20^{\circ} \mathrm{W}$ during the North Atlantic Bloom Experiment. Deep-Sea Res II 40: $75-90$

Harrison WG (1980) Nutrient regeneration and primary production in the sea. In: Falkowski PG (ed) Primary productivity in the sea. Plenum Press, New York, p 433-460

Harrison WG (1990) Nitrogen utilization in chlorophyll and primary productivity maximum layers: an analysis based on the $f$-ratio. Mar Ecol Prog Ser 60:85-90

Harrison WG (1992) Regeneration of nutrients. In: Falkowski PG, Woodhead AV (eds) Primary productivity and biogeochemical cycles in the sea. New York, Plenum Press, p 385-409

Healey FP (1978) Physiological indicators of nutrient deficiency in algae. Mitt Int Ver Theor Angew Limnol 21. $34-41$

Hecky RE, Kilham P (1988) Nutrient limitation of phytoplankton in freshwater and marine environments: a review of recent evidence on the effects of enrichment. Limnol Oceanogr 33:796-822

James B, Cotner JB, Wetzel RG (1991) 5'-nucleotidase activity in a eutrophic lake and an oligotrophic lake. Appl Environ Microbiol 57:1306-1312

Karl DM, Tien G (1992) MAGIC: a sensitive and precise method of measuring dissolved phosphorus in aquatic environments. Limnol Oceanogr 37:105-116

Klinker J, Reiss Z, Kropach C, Levanon I, Harpaz H. Halicz E, Assaf G (1976) Observations on the circulation pattern in the Gulf of Aqaba (Elat), Red Sea. Isr J Earth Sci 25: 85-103

Klinker J, Reiss Z, Levanon I, Harpaz H, Shapiro Y (1978) Nutrients and biomass distribution in the Gulf of Aqaba (Elat), Red Sea. Mar Biol 45:53-64

Korpal, T (1991) Dissolved nutrients in the reef of the northern Gulf of Elat-sources and fluxes. MSc thesis, Hebrew University

Krom MD, Brenner S, Kress N, Neori A, Gordon LI (1993) Nutrient distributions during an annual cycle across a warm-core eddy from the E-Mediterranean Sea. DeepSea Res 40:805-825

Krom MD, Kress N, Brenner S, Gordon LI (1991) Phosphorus limtation of primary productivity in the eastern Mediterranean Sea. Limnol Oceanogr 36:424-432

Lande R, Li WKW, Horne EPW, Wood A (1989) Phytoplankton growth rates estimated from depth profiles of cell concentration and turbulent diffusion. Deep-Sea Res 36: $1141-1159$

Levanon-Spanier I. Padan E, Reiss Z (1979) Primary production in a desert-enclosed sea - the Gulf of Elat (Aqaba), Red Sea. Deep-Sea Res 26:673-685

Lindell D, Post AF (1995) Ultraphytoplankton succession is triggered by deep winter mixing in the Gulf of Aqaba (Eilat), Red Sea. Limnol Oceanogr 40:1130-1141 
Liu H, Campbell L, Landry MR (1995) Growth and mortality of Prochlorococcus and Synechococcus measured with a selective inhibitor technique. Mar Ecol Prog Ser 116: $277-287$

Martin JH, Coale KH, Johnson KS, Fitzwater SE, Gordon RM, Tanner SJ, Hunter CN, Elrod VA, Nowicki JL, Coley TL, Barber RT, Lindley S, Watson AJ, Van Scoy K, Law CS, Liddicoat MI, Ling R, Stanton T, Stockel J, Collins C, Anderson A, Bidigare $R$, Ondrusek $M$, Latasa $M$, Millero FJ, Lee K, Yao W, Zhang JZ, Friederich G, Sakamoto C, Chavez F, Buck K, Kolber $Z$, Greene R, Falkowski PG, Chisholm SW, Hoge F, Swift R, Yungel J, Turner $S$, Nightingale P, Hatton A, Liss P, Tindale NW (1994) Testing the iron hypothesis in ecosystems of the equatorial Pacific Ocean. Nature 371:123-129

Murphy J, Riley JP (1962) A modified single solution method for the determination of dissolved phosphate in natural waters. Anal Chim Acta 27:31-36

Murray SP, Hecht A, Babcock A (1984) On the mean flow in Tiran Strait in winter. J Mar Res 42:265-287

Parpais J, Marie D, Partensky F, Morin P, Vaulot D (1996) Effect of phosphorus starvation on the cell cycle of the photosynthetic prokaryote Prochlorococcus spp. Mar Ecol Prog Ser 132:265-274

Ray JM, Bhaya D, Block MA, Grossman AR (1991) Isolation, transcription and inactivation of the gene for an atypical alkaline phosphatase of Synechococcus $\mathrm{sp}$. strain PCC7942. J Bacteriol 173:4297-4309

Reiss Z, Hottinger L (1984) The Gulf of Aqaba. Ecological micropalaeontology. Springer-Verlag, Berlin

Scanlan DJ, Mann NH, Carr NG (1993) The response of the picoplanktonic marine cyanobacterium Synechococcus WH7803 to phosphate starvation involves a protein homologous to the periplasmic phosphate-binding protein of Escherichia coli. Mol Microbiol 10:181-191

Scanlan DJ, Silman NJ, Donald KM, Wilson WH, Carr NG, Joint I, Mann NH (1997) An immunological approach to detect phosphate stress in populations and single cells of

Editorial responsibility: Graham Savidge (Contributing Editor), Portaferry, Northern Ireland photosynthetic picoplankton. Appl Environ Microbiol 63: 2411-2420

Sobecky PA, Schell MA, Moran MA, Hodson RE (1996) Impact of a genetically engineered bacterium with enhanced alkaline phosphatase activity on marine phytoplankton communities. Appl Environ Microbiol 62:6-12

Tomas CR, Baden DG (1993) The influence of phosphorus source on the growth and cellular toxin content of the benthic dinoflagellate Prorocentrum lima. In: Smayda TJ, Shimizu Y (eds) Toxic phytoplankton blooms in the sea, Vol 3. Elsevier Publ, Amsterdam, p 565-570

Vargo GA, Shanley E (1985) Alkaline phosphatase activity in the red-tide dinoflagellate, Ptychodiscus brevis. PSZN I: Mar Ecol 6:251-264

Vaulot D, LeBot N, Marie D, Fukai E (1996) Effect of phosphorus on the Synechococcus cell cycle in surface Mediterranean waters during summer. Appl Environ Microbiol 62:2527-2533

Vaulot D, Partensky F (1992) Cell cycle distribution of prochlorophytes in the northwestern Mediterranean Sea. Deep-Sea Res 39:727-742

Venrick EL, Cummings SL, Kemper CA (1987) Picoplankton and the resulting bias in chlorophyll retained by traditional glass-fiber filters. Deep-Sea Res 34:1951-1956

Wolf-Vecht A, Paldor N, Brenner S (1992) Hydrographic indications of advection/convection in the Gulf of Eilat. DeepSea Res 39:1393-1401

Wynne D (1981) The role of phosphatase in the metabolism of Peridinium cinctum from Lake Kinneret. Hydrobiol 83: 93-99

Wynne D, Bergstein-Ben Dan T (1995) The effect of light and phosphate concentrations on phosphatase activities of the photosynthetic bacterium Chlorobium sp. Can J Microbiol 41:278-283

Yentsch CM, Yentsch CS, Perras JP (1972) Alkaline phosphatase activity in the tropical marine blue-green alga, Oscillatoria erythraea ('Trichodesmium'). Limnol Oceanogr 17:772-774

Submitted: June 16, 1997; Accepted: August 3, 1998

Proofs received from author(s): October 21, 1998 